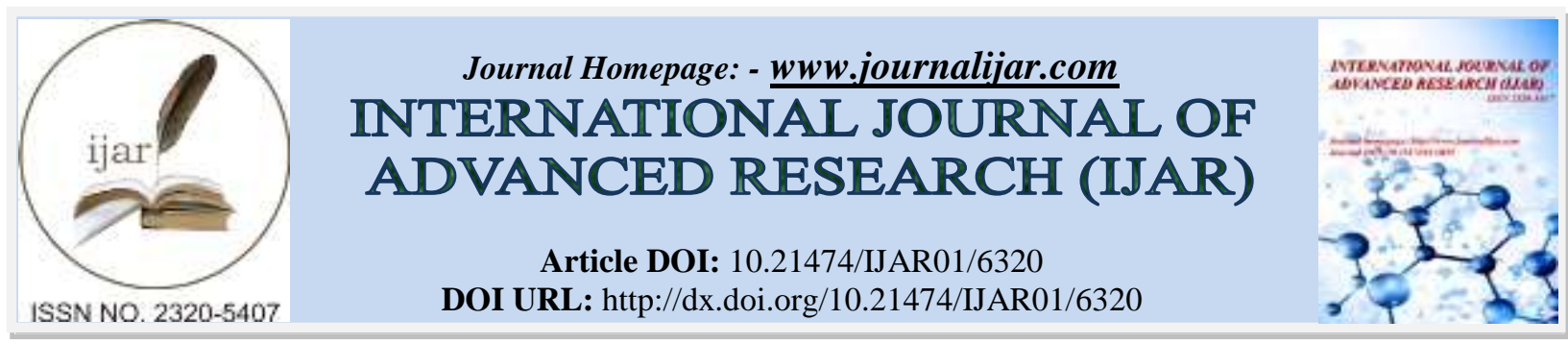

RESEARCH ARTICLE

\title{
MULTIPLE MAGNETS INGESTION - ALWAYS ON EMERGENCY.
}

\section{Prof.K.Mohankumar ${ }^{1}$ DCH., MS. M.Ch, Dr.V. gomathi ${ }^{2}$ MS. M. Ch, Dr. D.Vembar ${ }^{3}$ MS.M.Ch and Dr. Rohit} gopinath $^{4}$ MS M. Ch Resident.

1. Professor - Institute of child health .Egmore Madras Medical College.

2. Assistant Professor - Institute of child health .Egmore Madras Medical College.

3. Assistant Professor - Institute of child health .Egmore Madras Medical College.

4. Junior Resident - Institute of child health .Egmore Madras Medical College.

\section{Manuscript Info}

(.........................

Manuscript History

Received: 16 November 2017

Final Accepted: 18 December 2017

Published: January 2018

\section{Key words:-}

Neodymium Magnets,bowel

perforation,Laparotomy , ,X-ray

abdomen.

\section{Abstract}

Multiple magnet ingestion causes bowel entrapment and pressure necrosis.X-ray abdomen is diagnostic .CT and Ultra sonogram are not required .MRI is contraindicated.Laparatomy and magnet removal is the ideal treatment of choice .Laparoscopic sheath attracts magnets and aggravates bowel perforation.

\section{Summary:-}

In 10 years' experience in ICH-Egmore, we have studied 20 cases of magnet in children single magnet were expelled without difficulty in 17 cases. These patients were warned not to wear metal buttons on their dresses to avoid bowl entrapment and pressure necrosis. Multiple magnet ingestion in 3 children showed failure of progression beyond jejunum and perforation at 10 to $15 \mathrm{~cm}$ of Jejunum from fixed loop.

New generation magnets are made of iron ,boron and neodymium and are 10 times stronger and these are capable of attracting 6 layers of bowel .

These patients presented with abdominal pain\& vomiting and alleged history of magnet ingestion .Clinically abdomen is soft and peritonitis will not be there .But still laparotomy and magnets removal is mandatory to save the life of the children. 


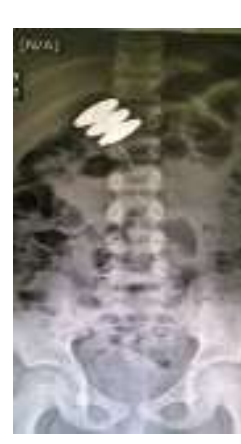

Case 1.Fig 1 and 2

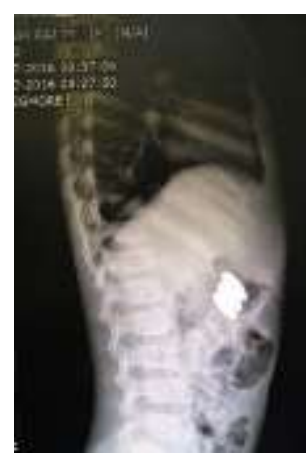

Case 2
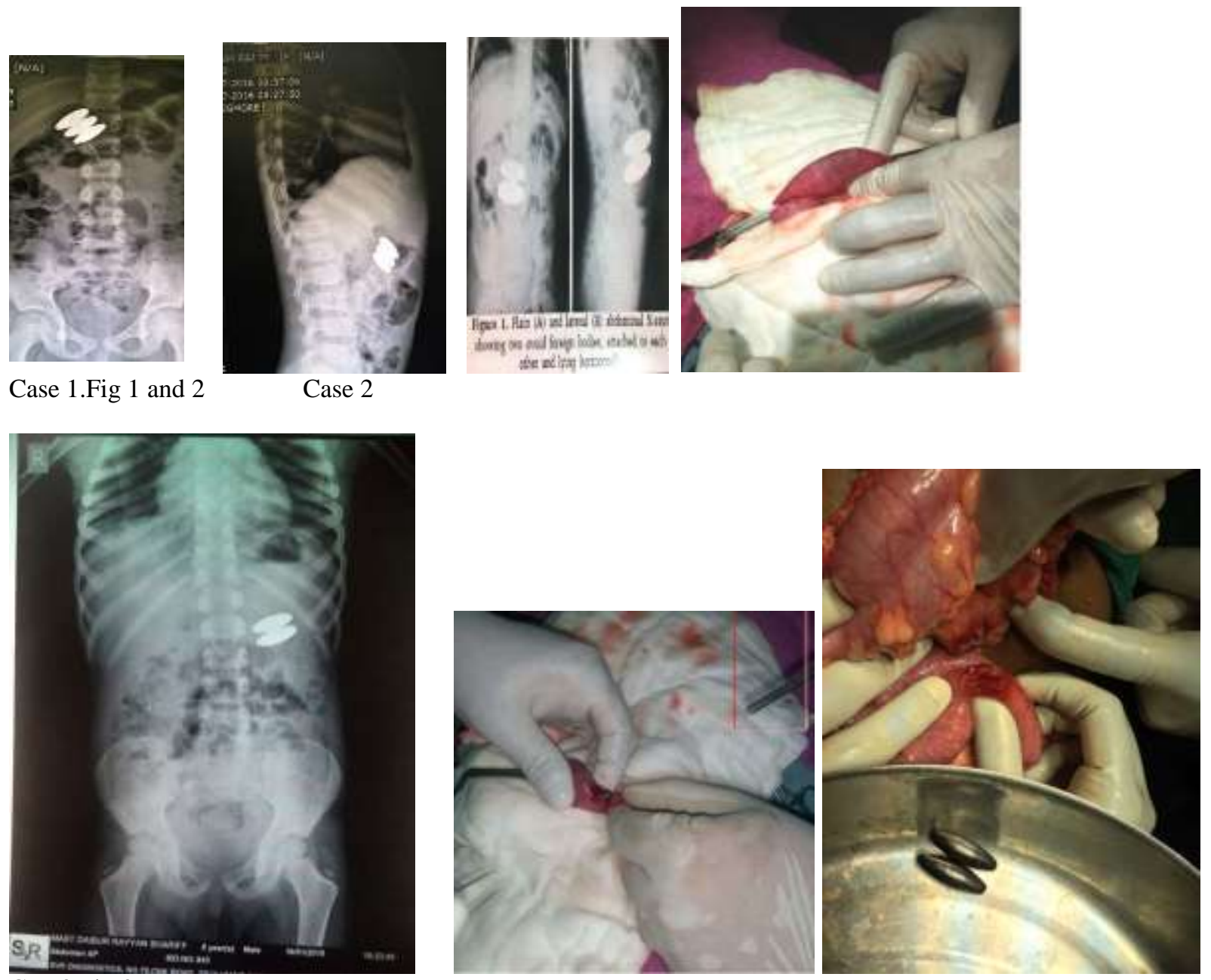

Case3.Fig.3

\section{Conclusion:-}

Endoscopy has limited role in the removal of magnets as they lead on to bowel perforation.Perforation needs perfect closure to avoid mortality.If history of magnets ingestion in children is less than 12 hours endoscopy can be attempted. Metal button should be avoided to avoid bowel necrosis.Surgery is the ideal treatment for multiple magnet ingestion.

1. multiple magnet ingestion: is there a role for early surgical intervention?[Ann Saudi Med. 2012]

2. Toy magnet ingestion in children: revising the algorithm. [J Pediatr Surg. 2007]

3. Multiple magnet ingestion: a real challenge for the paediatric surgeon. [Acta Clin Belg. 2012]

4. Magnets, children and the bowel: a dangerous attraction?[World J Gastroenterol. 2012]

5. Gastrointestinal damage caused by swallowing multiple magnets.[Front Med. 2012] 